\title{
ANALYSIS OF CEILING TYPE TO PRODUCE ENERGY EFFICIENT RESIDENTIAL BUILDINGS: CASE STUDY ON HOUSING DESIGN OF PUSKIM PU-BANDUNG CITY
}

\author{
ANALISIS TIPE PLAFOND/CEILING DALAM UPAYA MENGHASILKAN \\ BANGUNAN RUMAH TINGGAL HEMAT ENERGI: \\ STUDI KASUS DESAIN RENCANA PERUMAHAN SWADAYA PUSKIM \\ KEMENTRIAN PU-KOTA BANDUNG
}

\author{
Nurina Vidya Ayuningtyas", Istiana Adianti \\ Study Program of Architecture, Universitas Widya Mataram \\ Jatmika Adi Suryabrata \\ Department of Architecture and Planning, Universitas Gadjah Mada \\ Submitted:13-05-2020; Revised:25-08-2021; Accepted: 27-08-2021
}

\begin{abstract}
Many houses that exist on this earth. Therefore, it is necessary to have tactical and intelligent thinking in designing a home. Many things are rarely considered related to the effects of the design of building elements when related to the temperature or the energy produced. Existing background regarding efforts to reach a comfortable temperature can not only be solved in terms of mechanical systems, but the architectural approach can help and provide a comfortable effect for its inhabitants. This research was conducted to determine the level of thermal comfort or temperature in the room of a residential design that would be related to the size of energy consumption by applying several alternative designs or ceiling forms. This type of research is research using simulation methods through a computer model. The results showed the use of ceiling type Vaulted Ceiling was able to increase the Surface Inside Temperature value by $3^{\circ} \mathrm{C}$ when compared to the type of drop ceiling. The Mean Radiant Temperature value when using the ceiling vault type rises $0.6^{\circ} \mathrm{C}$ and on the acquisition of Operative, Temperature rises $0.3^{\circ}$ C. The use of insulation material on the roof can significantly reduce Mean Radiant Temperature and Operative Temperature at $1.7^{\circ} \mathrm{C}$ at Mean Radiant Temperature and $0.8^{\circ} \mathrm{C}$ at Operative Temperature. Seeing the results of the simulation in this study, the recommended ceiling type is to use the drop ceiling type because it is quite capable of keeping the temperature in the room not too high so that thermal comfort can be achieved. However, if you want to apply a ceiling design with a model or type of drop ceiling, it is better to use additional insulation material so that the heat transmission temperature is not too high in the room.
\end{abstract}

Keywords: Drop Ceiling; Vaulted Ceiling; Green Architecture; Energy-Saving Architecture; Thermal Comfort.

\footnotetext{
* Corresponding author: nurina.vidya@gmail.com

Copyright @2021 THE AUTHOR(S). This article is distributed under a Creative Commons Attribution-Share Alike 4.0 International license. Jurnal Teknosains is published by the Graduate School of Universitas Gadjah Mada
} 


\begin{abstract}
ABSTRAK
Begitu banyak rumah tinggal yang ada di muka bumi ini. Oleh karena itu, diperlukan adanya pemikiran yang taktis dan cerdas dalam mendesain sebuah rumah tinggal. Banyak hal yang jarang diperhatikan terkait efek dari desaindesain elemen-elemen bangunan ketika dikaitkan dengan suhu ataupun energi yang dihasilkan. Latar belakang yang sudah ada mengenai upaya mencapai suhu yang nyaman ini tidak dapat hanya diselesaikan dari sisi sistem mekanikalnya, namun pendekatan arsitektural mampu membantu dan memberikan efek nyaman bagi penghuninya. Penelitian ini dilakukan dengan tujuan untuk mengetahui tingkat kenyamanan termal atau suhu di dalam ruangan sebuah desain rumah tinggal yang akan berkaitan besar kecilnya konsumsi energi dengan menerapkan beberapa alternative desain atau bentuk plafond. Jenis penelitian ini adalah penelitian dengan menggunakan metode simulasi melalui model komputer (computer model). Hasil penelitian menunjukkan Penggunakan tipe ceiling Vaulted Ceiling mampu menaikkan nilai Surface Inside Temperature sebesar $3^{\circ} \mathrm{C}$ jika dibandingkan dengan tipe drop ceiling. Nilai Mean Radiant Temperature ketika mengunakan tipe vaulte ceiling naik $0.6^{\circ} \mathrm{C}$ dan pada perolehan Operative Temperature naik $0.3^{\circ} \mathrm{C}$. Penggunaan material insulasi di atap mampu menurunkan suhu Mean RadiantTemperature dan Operative Temperature yang cukup signifikan yaitu $1.7^{\circ} \mathrm{C}$ pada Mean Radiant Temperature dan $0.8^{\circ} \mathrm{C}$ pada Operative Temperature. Melihat hasil dari simulasi pada penelitian ini, tipe ceiling yang disarankan yaitu menggunakan tipe drop ceiling karena cukup mampu menjaga suhu di dalam ruangan tidak terlalu tinggi sehingga kenyamanan termal dapat tercapai. Namun apabila ingin menerapkan desain ceiling dengan model atau tipe drop ceiling maka sebaiknya menggunakan material insulasi tambahan agar transmisi suhu panas tidak terlalu tinggi yang masuk ke dalam ruangan.
\end{abstract}

Keywords: Drop Ceiling; Vaulted Ceiling; Arsitektur Hijau; Arsitektur Hemat Energi; Kenyamanan Termal.

\section{INTRODUCTION}

The building has become one of the biggest energy contributors in the world. Moreover, buildings with residential functions. So many homes that exist on this earth. Therefore, it is necessary to have tactical and intelli- gent thinking in designing a home. One of the sectors that have been the biggest energy consumption aside from the industrial and transportation sectors is the building sector (IFC, 2011). However, we actually can still reduce the large energy requirements if we can apply development concepts that are adaptive to the environment and are efficient in energy use.

It should be noted that the shapes and types of each design element in a building greatly affect the comfort which is indirectly closely related to the size of the energy consumption of the building. In this study, the highlighted buildings tend to be residential buildings which are the design plans of the Ministry of Public Works Settlement Center which will be implemented in the city of Bandung. This residential design will be a pilot residential design that carries the concept of energy-efficient residential. In collaboration with the International Finance Corporation (Green and Energy Efficient Building Division), research is carried out related to the effects of building elements, especially ceiling/ceiling which are then observed related to the thermal temperature generated in it along with the effect on the energy efficiency of a building (BSN, 2001). The comfort factor is an important element that must be achieved from a building. To achieve this comfort can be achieved with the building itself (passively) or by using energy resources (actively). Many things are rarely considered related to the effects of the design of building elements when related to the temperature or the energy produced (BSN, 2000).

In this research, what is more, highlighted is related to the selection in applying the ceiling in a residential house? Although far from the reach of human hands, the ceiling becomes an important element in a space in the building. Therefore, made several types and forms of ceiling designs that can be selected by all people with diverse designs. Several forms and types of ceilings can be categorized, including flat ceilings and sloping ceilings (Akmal, 2008). The flat ceiling type is the most common. This ceiling design is often given a name or fills "Drop Ceiling". 
Previously, this ceiling design was formed from multiplex panels that were limited by trim or grout. But at this time as technology develops, flat ceilings appear with shapes that have a flat surface without trim or grout because the trim or grout, if there is will be as small or as thin as possible. In addition to being installed attached to the ceiling frame, a flat ceiling can also be made hanging. Hanging ceiling or so-called suspended ceiling is usually used in rooms with very high ceilings but wants to be made lower. The second type is the sloping ceiling. The sloping ceiling is a ceiling that has one or more sloping fields that shade a room. The sloping ceiling is formed because it follows the shape of the roof truss structure above it. Lately many problems have arisen in residential buildings related to thermal discomfort when in the house caused by improper ceiling designs

\section{METHOD}

This type of research is research using simulation methods through a computer model. According to the book Architectural research methods Groat and Wang (2002) in Saud (2012), that simulation is conditioning a form of real-context into a replica form (or a hypothesis of a real-world context). The software used includes Energy Plus and Bandung City Climate Data. The building that will be simulated is made as closely as possible with the design proposed by PUSKIM PU Bandung. The geometry can be seen as shown in Figure 1.
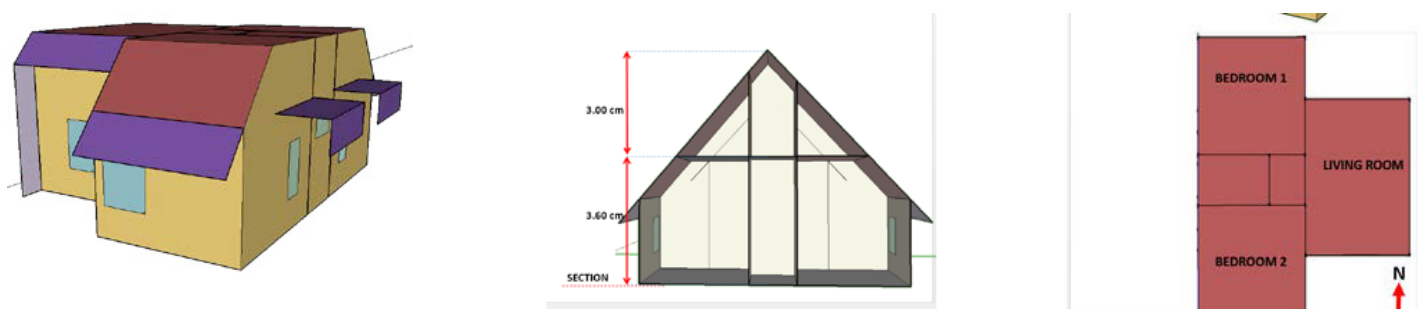

Figure 1.

Modeling of Buildings in Simulation

Source: Data analysis (2019)

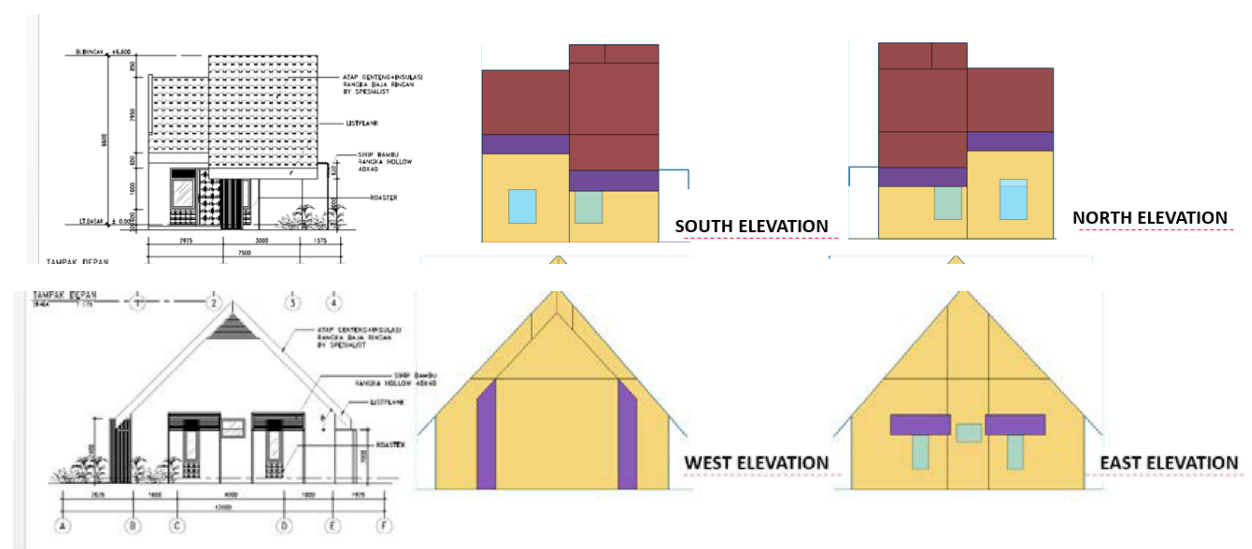

Figure 2.

Building Elevation in Simulation

Source: Data analysis (2019)

The function of the building to be released is a residence that is expected to be active throughout the day. The acquisition of inter- nal heat (internal heat gain) with the function of office buildings following the standards set by SNI and Ministry of Public Works. 
Table 1.

Internal Load Input for Offices according to SNI and Ministry of Public Works Decree

\begin{tabular}{l|l|l}
\hline \multicolumn{1}{c|}{ Internal Load Type } & \multicolumn{1}{|c}{ Breakdown } & The amount of Internal Load \\
\hline Occupancy & Occupancy (person/m2) & 0.1 \\
\hline Artificial Lighting & Fraction Radiant & 0.3 \\
\hline & $\begin{array}{l}\text { Sensible Heat Fraction } \\
\text { Activity Level } \\
\text { Cloth }\end{array}$ & $\begin{array}{l}\text { Autocalculate } \\
140 \mathrm{~W} / \text { person }\end{array}$ \\
& $\begin{array}{l}\text { Lighting level }(\mathrm{W} / \mathrm{m} 2) \\
\text { Illumination target }(\mathrm{lux})\end{array}$ & $\begin{array}{l}0.5 \\
8\end{array}$ \\
& Fraction Radiant & 350 \\
& Fraction Visible & 0.37 \\
& Watts per Zone Floor Area $(\mathrm{W} / \mathrm{m} 2)$ & 0.18 \\
\hline Electrical equipment & Fraction Radiant & 10 \\
& Schedule of activities & 0.2 \\
& & $00.00-24.00$ \\
\hline
\end{tabular}

Source: Data analysis (2019)

\section{RESULTS AND DISCUSSION}

In this study, modeling was carried out with three types of ceilings as well as independent variables of this study, namely the Drop Ceiling type, Vaulted Ceiling type and, Vaulted Ceiling type with insulation. These three types are most often applied in the country of Indonesia so it is necessary to study which type is most effective to apply to residential housing. While the dependent variables used include brick wall material, glass material in the form of clear $8 \mathrm{~mm}$ glass and, metal roofing material. The selection of bound variables is chosen based on the char- acteristics of the material that has the lowest thermal value compared to the others.

Then for the output used to analyze include surface inside temperature, mean radiant temperature and, operative temperature.

\section{Surface Inside Temperature}

The surface inside temperature is the amount of temperature or temperature that is owned by the innermost layer seen from inside the room. This deepest layer which is usually a layer of interior walls that is very influential on the temperature conditions in the room.

Table 2.

Surface Inside Temperature Simulation Results for Drop Ceiling models, Vaulted Ceiling type and Vaulted Ceiling type with insulation

\begin{tabular}{|c|c|c|c|c|c|}
\hline \multicolumn{6}{|c|}{ DROP CEILING (WITHOUT INSULATION) } \\
\hline & CEILING & $\begin{array}{l}\text { NORTH } \\
\text { WALL }\end{array}$ & EAST WALL & SOUTH WALL & WEST WALL \\
\hline Living Room & 36.77 & 30.34 & 31.51 & 30.38 & 0 \\
\hline Bedroom 1 & 37.20 & 0 & 31.45 & 30.67 & 30.82 \\
\hline Bedroom 2 & 36.84 & 29.97 & 30.75 & 0 & 30.55 \\
\hline
\end{tabular}




\begin{tabular}{|c|c|c|c|c|c|}
\hline \multicolumn{6}{|c|}{ VAULTED CEILING (WITHOUT INSULATION) } \\
\hline & CEILING & $\begin{array}{l}\text { NORTH } \\
\text { WALL }\end{array}$ & EAST WALL & SOUTH WALL & WEST WALL \\
\hline Living Room & 39.78 & 30.39 & 31.74 & 30.85 & 0 \\
\hline Bedroom 1 & 39.89 & 0 & 30.11 & 31.12 & 31.13 \\
\hline Bedroom 2 & 39.63 & 30.35 & 31.11 & 0 & 30.87 \\
\hline \multicolumn{6}{|c|}{ VAULTED CEILING (WITH INSULATION) } \\
\hline & CEILING & $\begin{array}{l}\text { NORTH } \\
\text { WALL }\end{array}$ & EAST WALL & SOUTH WALL & WEST WALL \\
\hline Living Room & 32.31 & 29.49 & 30.87 & 29.96 & 0 \\
\hline Bedroom 1 & 32.54 & 0 & 29.08 & 30.29 & 30.49 \\
\hline Bedroom 2 & 32.17 & 29.48 & 30.27 & 0 & 30.01 \\
\hline
\end{tabular}

Source: Data analysis (2019)

Seeing the simulation results obtained, it can be seen that the highest Surface Inside Temperature results are in the interior ceiling layers compared to other interior walls. This is because the interior ceiling layer is affected by the temperature transmitted from the roof directly. Then when compared with the three simulated ceiling types, the vaulted ceiling type that gets the highest Surface Inside Temperature value because the ceiling layer in this type gets a direct transmission from the roof without any space/heat intermediate layer as found in the drop ceiling type or the type that uses insulation.

When analyzing the results obtained from the interior walls in the four cardinal directions, then the wall in the West obtains the highest temperature results and the south di- rection wall obtains the lowest temperature or temperature results in the three ceiling type simulation models. The results obtained are like this because the simulated area is the area south of the equator so that the lowest solar gain in the southern area and westward arena receive solar heat throughout the day compared to the east and the other then the west receives the highest heat exposure.

\section{Mean Radiant Temperature}

The second benchmark is Mean Radiant Temperature which is the average temperature value generated by all surfaces in the building including the temperature of the equipment in the building (ISO, 2005). The assumption of equipment used in this building is the same as household appliances in general that operate for almost 24 hours. 
Table 3.

Mean Radiant Temperature Simulation Results for Drop Ceiling models, Vaulted Ceiling types and Vaulted Ceiling types with insulation

\begin{tabular}{l|l|l|l}
\hline & $\begin{array}{c}|c| \\
\text { DROP CEILING } \\
\text { (WITHOUT INSULATION) }\end{array}$ & $\begin{array}{c}\text { VAULTED CEILING } \\
\text { (WITHOUT INSULATION) }\end{array}$ & $\begin{array}{c}\text { VAULTED CEILING (WITH } \\
\text { INSULATION) }\end{array}$ \\
\hline Living Room & 30.34 & 30.94 & 29.20 \\
\hline Bedroom 1 & 30.51 & 31.12 & 29.49 \\
\hline Bedroom 2 & 30.14 & 30.75 & 29.08 \\
\hline
\end{tabular}

Source: Data analysis (2019)

Mean Radiant Temperature simulation results show the average in three rooms that have the same characteristics, namely the highest Mean Radiant Temperature value is in the vaulted ceiling type and the lowest is in the vaulted ceiling type with insulation. This is because the type of vaulted ceiling has an interior surface layer that can be used as a field of heat transmission for more sunlight than the drop ceiling type. Then the type of vaulted ceiling with insulation has the lowest results due to the help of an insulation layer that can hold the heat in or transmitted into the room.

\section{Operative Temperature}

When talking about thermal comfort in space certainly will not escape by making the temperature indicator as a benchmark (Lechner, 2001). The actual indicator must be considered in achieving the level of human comfort that inhabits the space is the Operative Temperature value, where the Operative Temperature is the average value of the sum of air temperature and mean radiant temperature and is the temperature felt directly by human skin (Jain, 2011).

Table 4.

Results of Operative Temperature Simulation for Drop Ceiling models, Vaulted Ceiling types and Vaulted Ceiling types with insulation

\begin{tabular}{l|l|l|l}
\hline & \multicolumn{1}{|c|}{ DROP CEILING } & \multicolumn{1}{|c|}{$\begin{array}{c}\text { VAULTED CEILING } \\
\text { (WITHOUT INSULATION) }\end{array}$} & $\begin{array}{l}\text { VAULTED CEILING (WITH } \\
\text { (WITHOUT INSULATION) }\end{array}$ \\
\hline Living Room & 28.67 & 28.97 & 28.10 \\
\hline Bedroom 1 & 28.76 & 29.07 & 28.25 \\
\hline Bedroom 2 & 28.57 & 28.88 & 28.04 \\
\hline
\end{tabular}

Source: Data analysis (2019)

Looking at Table 4 above, the acquisition of Operative Temperature values obtained shows the similarity of characteristics or is directly proportional to the acquisition of Surface Inside Temperature and Mean Radiant Temperature values. The highest value or the hottest temperature is obtained in the vaulted ceiling type. This is because the Operative Temperature is the average value obtained from the Mean Radiant Temperature and Air Temperature values, in this research simulation the Air Temperature value is kept constant at $25^{\circ} \mathrm{C}$. this condition that affects the acquisition of the Operative Temperature value is strongly influenced by the
Mean Radiant Temperature. Also, the value of Mean Radiant Temperature is very largely influenced by Surface Inside Temperature because the inner/interior wall layers can produce heat which will affect Mean Radiant Temperature and Operative Temperature (Leung, 2012).

\section{CONCLUSION}

Using the Vaulted Ceiling type can increase the Surface Inside Temperature value by $3^{\circ} \mathrm{C}$ compared to the drop ceiling type. The Mean Radiant Temperature value when using the ceiling vault type rises $0.6^{\circ} \mathrm{C}$ and on the acquisition of Operative, Temperature 
rises $0.3^{\circ} \mathrm{C}$. The use of insulation material on the roof can significantly reduce Mean Radiant Temperature and Operative Temperature at $1.7^{\circ} \mathrm{C}$ at Mean Radiant Temperature and $0.8^{\circ} \mathrm{C}$ at Operative Temperature.

Seeing the results of the simulation in this study, the recommended ceiling type is to use the drop ceiling type because it is quite capable of keeping the temperature in the room not too high so that thermal comfort can be achieved. But if you want to apply a ceiling design with a model or type of drop ceiling, it is better to use additional insulation material so that the transmission of heat is not too high to enter the room. designer to know the shape of the ceiling that supports the comfort of residents. The results of this study are expected to provide input to the government, especially those focused on reducing energy use in Indonesia to support the government's program in reducing energy use, especially from the building sector.

\section{Acknowledgements}

The author would like to thank the support of Universitas Widya Mataram, Design Performa Energy Laboratory and, also thank the reviewer for their valuable comments to revise the paper.

\section{BIBLIOGRAPHY}

Akmal, Imelda. 2008. Plafond Kreatif. Gramedia. Jakarta .

Badan Standarisasi Nasional (BSN). 2000 . Konservasi Energi Selubung Bangunan pada Bangunan Gedung, SNI 03-63892011. BSN. Jakarta.

Badan Standarisasi Nasional (BSN). 2001. Tata cara perancangan sistem ventilasi dan pengkondisian udara pada bangunan gedung, SNI 03-6572- 2001. BSN. Jakarta.
International Finance Corporation (IFC). 2011. Jakarta Building Energi Efficiency Baseline and Saving Potential Sensitivity Analysis. IFC. Jakarta.

International Organization for Standarization (ISO). 2005. Ergonomics of the thermal environment - Analytical determination and interpretation of thermal comfort using calculation of the PMV and PPD indices and local thermal comfort criteria, ISO EN 7730. 2005.. International Organization for Standardization. Switzerland.

Groat, L., \& Wang, D. (2002). Architectural Research Methods. New York: John Wiley and Sons, Inc

Jain, Vaibhav. 2011. Effect of Operative Temperature Based Thermostat Control As Compared to Air temperature Based Control On Energi Consumption in Highly Glazed Building. Sidney : 12th Conference of International Building Performance Simulation Association: 3-4

Lechner, N. 2001. Heating, Cooling, Lighting metode Desain untuk Arsitektur. Rajagrafindo Persada. Jakarta.

Leung, Christ. Dkk 2012. Sleep Thermal Comfort And The Energi Saving Potential Due To Reduced Indoor Operative Temperature During Sleep. Department Of Building, Civil And Environmental Engineering, Concordia University, Montreal, Canada.

Saud, Ibnu. 2012. Pengaruh Konfigurasi Window To Wall Ratio, Solar Heat Gain Coefficient Dan Orientasi Bangunan Terhadap Kinerja Termal Selubung Bangunan. Yogyakarta: Universitas Gadjah Mada. 